\title{
Technology of groundwater biological deferrization
}

\author{
Zhanna Govorova*, Ekaterina Muraveva, Vadim Govorov and Vasiliy Semenovykh \\ Moscow State University of Civil Engineering, 26, Yaroslavskoe shosse, 129337 Moscow, Russia
}

\begin{abstract}
Applicability of development of technology using bioreactor and floating media filter is shown. The technology is based on the biological oxidation of iron and manganese by a group of iron oxidizing bacteria (IOB). The description, the operating principle and the results of technology testing are given. If the content of iron is $4,9-5,71 \mathrm{mg} / \mathrm{L}$, manganese $-0,12-0,2 \mathrm{mg} / \mathrm{L}$ and carbon dioxide and hydrogen sulphide are present, the quality of treated water meets all normative requirements. A microscopic analysis of the backwash water from bioreactor and filter was carried out. It has been established that Leptothrix type iron oxidizing bacteria are involved in the oxidation of compounds of dissolved forms of iron and manganese.
\end{abstract}

\section{Introduction}

Providing the population high-quality drinking water is one of the important and toppriority problems. Over the last years artesian groundwater is widely used as a water supply source. Groundwater contains iron and manganese compounds, dissolved gases and biogenous components. The presence of iron in the water conduces to the corrosion of pipes, debases the organoleptic properties of water and adversely affects the human body. The presence of manganese in water leads to the deposit accumulation in distribution system piping network. Dissolved gases (hydrogen sulfide and carbon dioxide) have negative impact in the process of water deferrization, therefore preliminary degasification is required.

Various reagent and reagentless technologies are used to remove dissolved iron and manganese from groundwater. [1]. Reagentless technologies are more preferable. It involves water aeration and filtration through inert medium. Using pumps for water boosting and backwashing filter media, compressors for pressure air supply in watertreatment systems and complicates the maintenance.

Due to this, one of the perspective directions is a development of technology that uses bioreactor and floating expanded polystyrene media filter [2,3]. According to [4] iron in natural water could be oxidized either chemical or biological ways, depending on physicochemical composition and presence of iron oxidizing bacteria (IOB).

*Corresponding author: GovorovaZhM@mgsu.ru 
The basis of technology is a biological oxidation of iron and manganese using IOB which can be found in groundwater depending of Eh and $\mathrm{pH}$ (Table 1) [5]. Biological deferrization and demanganation are used widely in water-treatment systems all around the world [5-11].

Table 1. Field of existence of iron oxidizing bacteria.

\begin{tabular}{|c|c|c|}
\hline Group & Species & Field of existence \\
\hline $\begin{array}{c}\text { Acidophilic } \\
\text { chemolithotrops }\end{array}$ & Thiobacillus & $\begin{array}{c}\text { High value of } \mathrm{Eh}, \\
\text { Low value of } \mathrm{pH}\end{array}$ \\
\hline $\begin{array}{c}\text { Microaerophilic } \\
\text { chemolithotrophics and } \\
\text { organotrophics }\end{array}$ & $\begin{array}{c}\text { Gallionella, Leptothrix, } \\
\text { Crenothrix }\end{array}$ & $\begin{array}{c}\text { Moderate value of Eh, } \\
\text { Neutral value of } \mathrm{pH}\end{array}$ \\
\hline $\begin{array}{c}\text { Chemoorganotrophics, } \\
\text { destroying iron organic } \\
\text { cpompouds }\end{array}$ & Arthrobacter & $\begin{array}{c}\text { High value of } \mathrm{Eh}, \\
\text { Neutral value of } \mathrm{pH}\end{array}$ \\
\hline
\end{tabular}

Field of activity of biochemical processes proceeding due to the activity of IOB is shown on Fig. 1 [10].

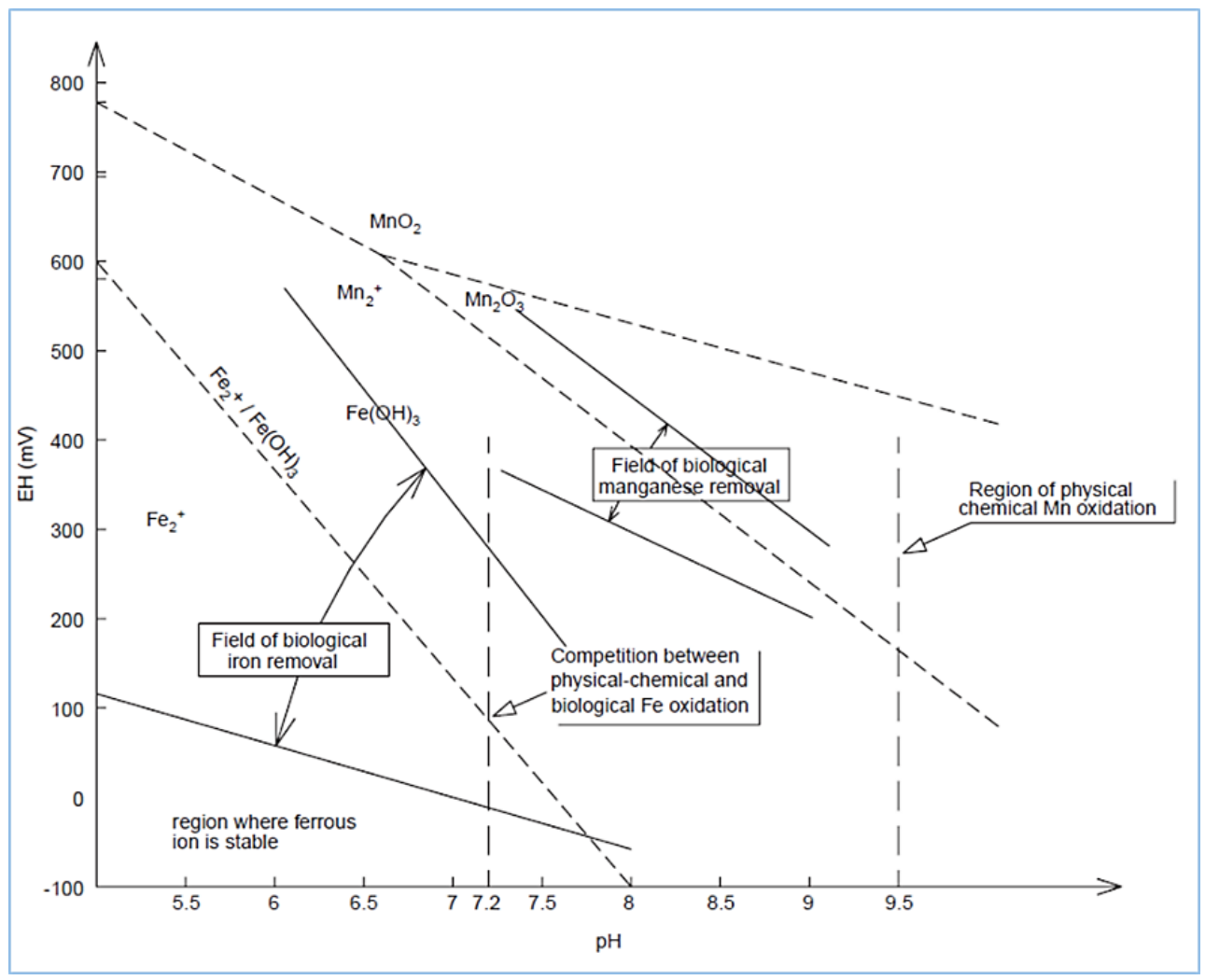

Fig. 1. Field of activity of $\mathrm{Fe}$ and Mn oxidizing bacteria in a pH-Eh diagram [10].

Life-sustaining activity of IOB is connected to the presence of Fe (II) and dissolved oxygen in them [12]. Fe (II) is present in groundwater in the form of inorganic compounds or organo-mineral complex with humic compounds. IOB oxidize dissolved in water Fe(II) to $\mathrm{Fe}(\mathrm{III})$. 


$$
4 \mathrm{Fe}\left(\mathrm{HCO}_{3}\right)_{2}+\mathrm{O}_{2}+2 \mathrm{H}_{2} \mathrm{O}=4 \mathrm{Fe}(\mathrm{OH})_{3}+8 \mathrm{CO}_{2}+81 \mathrm{kcal}
$$

Per $1 \mathrm{~g}$ of synthesized cellular element, IOB oxidize $279 \mathrm{~g}$ of $\mathrm{Fe}(\mathrm{II})$ forming $534 \mathrm{~g}$ of iron hydroxide(III). The correlation between oxidized Fe and assimilated from carbonic acid carbon (500:1) shows how large is the amount of hydroxide forming during autotrophic growth. Some species of IOB can oxidize $\mathrm{Mn}^{+2}$ in the absence of $\mathrm{Fe}^{+2}$ in water according to the following reaction:

$$
2 \mathrm{Mn}\left(\mathrm{HCO}_{3}\right)_{2}+\mathrm{O}_{2}=2 \mathrm{MnO}_{2}+4 \mathrm{CO}_{2}+2 \mathrm{H}_{2} \mathrm{O}
$$

Processes of physicochemical and biological deferrization occur simultaneously but with different rates of effectiveness. In cases when the presence of some inhibitors reduces the oxidation rate, process of biological deferrization and demanganation may become predominant.

\section{Materials and methods}

The study of the water treatment using mentioned process was carried out at a deferrization station. A model set, which consisted of two main units - bioreactor and floating media filter, was mounted (Fig. 2). The structure and composition of residual of backwash water were studied.

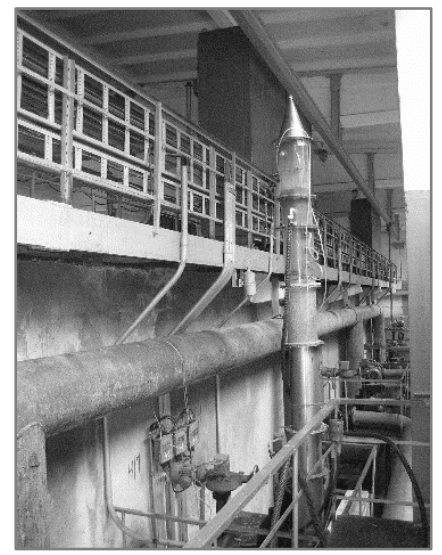

(a)

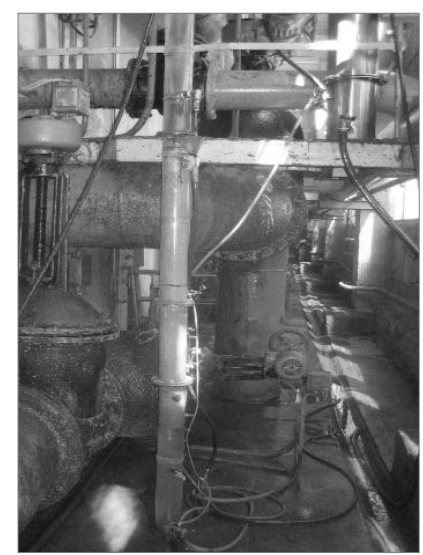

(b)

Fig. 2. General view of model set: a) bioreactor, b) filter.

Characteristics of floating media are given in Table 2. The filtration rate of bioreacor is $25 \mathrm{~m} / \mathrm{s}$, filter $-7,8-8 \mathrm{~m} / \mathrm{h}$.

Table 2. Characteristics of floating media.

\begin{tabular}{|c|c|c|}
\hline Parameter & Bioreactor & Filter \\
\hline Media size, mm & 6 & $1-1.8$ \\
\hline Layer thickness, $\mathrm{m}$ & 1.4 & 1.5 \\
\hline
\end{tabular}


Operating principle of the station was the following. Groundwater was fed from water pipe to the upper part of bioreactor, where it was splashed through the nozzle system and then filtrated through expanded polystyrene media. Carbon dioxide and hydrogen sulfide were stripped from the bioreactor, water was saturated with atmospheric oxygen and partial oxidation of $\mathrm{Fe}(\mathrm{II})$ to $\mathrm{Fe}(\mathrm{III})$ occurred. After the bioreactor, water entered the filter, where the final water cleaning from iron hydroxide occurred. Backwash of filter media was held once a day. Purified water from the space above the filter was used for filter backwash.

HI98128 pHep 5 test meter, water resistant pH/C/F-meter, Ecotest-120-pH-M analyzer, ProfiLine Oxi 3205 dissolved oxygen meter, colorimetric kits and HACH 1467-01 comparator for iron detection and HACH1467-00 comparator for manganese detection were used for the real-time analysis of water quality by $\mathrm{pH}$, Eh, concentrations of oxygen, total iron and manganese. Electronic microscope (Quanta $250 \mathrm{FEI}$ ) was used for the microscopic analysis of the sediment.

\section{Results}

Groundwater had unpleasant taste and hydrosulfuric odor. Odor intensity was 2-3 points. Carbon dioxide concentration was $75,4 \mathrm{mg} / \mathrm{L}$, iron - up to $5,71 \mathrm{mg} / \mathrm{L}$, manganese - up to $0,2 \mathrm{mg} / \mathrm{L}, \mathrm{pH}$ varied from 7,02 to 7,14, Eh was negative and did not exceed $-22,3 \mathrm{mV}$. Process stabilization of water purification from iron took 2-3 days, manganese $-4-5$ months.

Results are shown in table 3. It was established that $26 \%$ of carbon dioxide was stripped during the purification process. Oxygen concentration increased approximately 3 times. During the purification process, Eh rose from -22.3 to $+110 \mathrm{mV}$. Iron and manganese concentrations in purified water do not exceed permissible exposure limit.

Media backwash of bioreactor and filter was made with the intensity of 14 and 28 $\mathrm{L} / \mathrm{s} \cdot \mathrm{m}^{2}$ respectively. It was established that the bulk of contamination was carried out within the first 1,5 minutes and by the end of the $4^{\text {th }}$ minute iron concentration in the backwash water did not exceed $0,3 \mathrm{mg} / \mathrm{L}$. Expansion ratio of expanded polystyrene media layer was $35 \%$.

Two samples of backwash water were taken for the analysis: after the bioreactor and after the filter, to study the structure and composition of residual. Photomicrographs of backwash water residual after bioreactor and filter are shown in Fig. 3.

In the backwash water residual iron $(34,91 \ldots 59,09 \%)$, oxygen $(23,50 \ldots 44,96 \%)$ and carbon $(5,28 \ldots 7,53 \%)$ predominated, but nitrogen $(1,05 \ldots 1,95 \%)$ and other components were also found.

Table 3. Effectiveness of water purification process.

\begin{tabular}{|c|c|c|}
\hline Parameter & Groundwater & Purified water \\
\hline Temperature, ${ }^{\circ} \mathrm{C}$ & $10.1-11$ & $13-14$ \\
\hline Odor, point & $2-3$ & - \\
\hline Total Fe, mg/L & $4.9-5.71$ & $0.05-0.1$ \\
\hline $\mathrm{Mn}, \mathrm{mg} / \mathrm{L}$ & $0.12-0.2$ & $0.08-0.1$ \\
\hline $\mathrm{pH}$ & $7.02-7.14$ & $7.1-7.2$ \\
\hline
\end{tabular}




\begin{tabular}{|c|c|c|}
\hline Eh, $\mathrm{mV}$ & -22.3 & +110 \\
\hline Carbon dioxide, $\mathrm{mg} / \mathrm{L}$ & 75.4 & 55.8 \\
\hline Oxygen, $\mathrm{mg} / \mathrm{L}$ & $1.2-1.4$ & $3.5-4.2$ \\
\hline
\end{tabular}

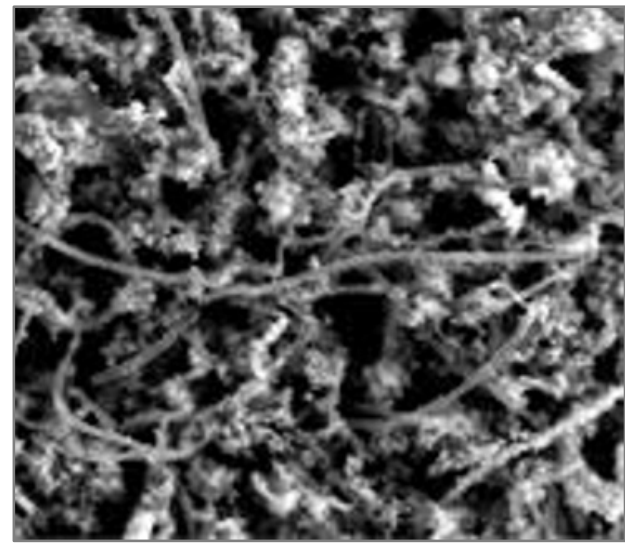

(a)

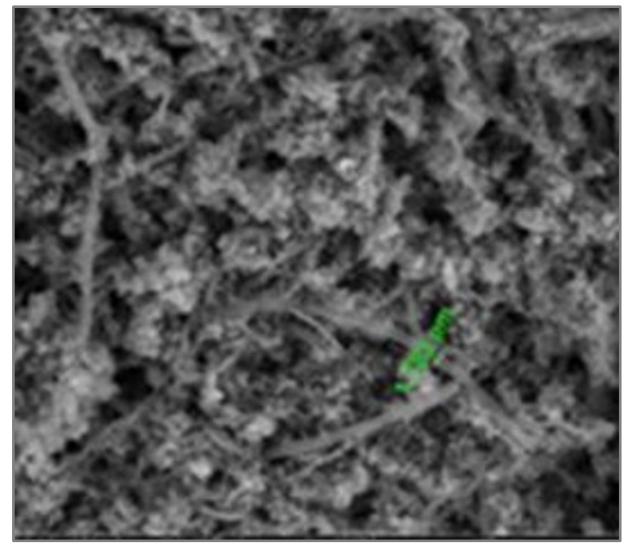

(b)

Fig. 3. Photomicrographs of backwash water residual: a) bioreactor, b) filter.

Microscopic analysis of all samples of residual showed the presence of typical mucous layer covered with iron hydroxide, produced by filamentous microorganisms called Leptothrix. A sample of bioreactor resudual (Fig. 3 (a)) showed not only mucous layers but also the presence of separate large conglomerates. This is attributed to the insignificant accumulation of residual in expanded polystyrene layer due to its partial washout under permanent downward groundwater flow at a speed of $16-18 \mathrm{~m} / \mathrm{h}$.

\section{Conclusions}

Appliance of reagentless technology using bioreactor and floating media filter was justified for groundwater treatment. It has been experimentally proven that this technology provides water of drinking quality with the content of total $\mathrm{Fe}$ not more than $5,7 \mathrm{mg} / \mathrm{L}$ and manganese not more than $0,2 \mathrm{mg} / \mathrm{L}$.

Obtained results correlate with study outcome of biological deferrization and demanganation of other authors.

Microscopic analysis of backwash water residual from bioreactor and filter showed the presence of mucous layer of filamentous microorganisms called Leptothrix.

Further studies should be aimed at the identification of IOB groups involved in biological oxidation, their quantitative accounting in backwash water residual, source and purified water.

\section{References}

1. G.I. Nikoladze, Uluchsheniye kachestva podzemnykh vod (Improvement of groundwater quality) (Stroyizdat, 1987) 
2. M.G. Zhurba, Vodoochistnyye fil'try s plavayushchey zagruzkoy (Floating-water treatment filters) (Moscow, 2011)

3. O.B. Govorov, V.O. Govorov, VST, 1-2, 26-35 (2016)

4. M.N. Mencha, Vodosn. i san. tekhnika, 7, 25-35 (2006)

5. P. Mouchet, G.N. Gerasimov, Vodosn. i san. tekhnika, 12, 35-39 (2011)

6. Q. Cheng, L. Nengzi, L. Bao, J. Water Sup.: R. and Techn.-AQUA, 3, 157-165 (2017)

7. L. Breda, L. Ramsay, P. Roslev, J. Water Sup.: R. and Techn.-AQUA, 8, 641-650 (2017)

8. J. Dusseldorp, K. Joris, K. Huysman, J. of Water Sup.: R. and Techn.-AQUA, 3, 195207 (2016)

9. T. Miyajima, Achiv. of Microbiol., 158, 100-106 (1992)

10. P. Mouchet, AWWA, 84/4, 158-167 (1992)

11. S. Hedrich, M. Schlomann, D.B. Johnson, Microbiol., 157, 1551-1564 (2011)

12. A.A. Askerniya, A.Yu. Sorokina, G.A. Dubinina, Vodosn. i san. tekhnika, 12, 14-20 (2014) 